\title{
The Impact of Micro-finance on Self-employment and Poverty Reduction: A case of Sindh Rural Support Organization and Tameer Micro Finance Bank, Sindh
}

\section{El impacto de las microfinanzas en el autoempleo y la reducción de la pobreza: un caso de Sindh Rural Support Organization y Tameer Micro Finance Bank, Sindh}

Received: June 12, 2020

Accepted: August 18, 2020

\author{
Written by: \\ Israr Ahmed ${ }^{5}$ \\ Imamuddin Khoso ${ }^{6}$
}

\begin{abstract}
Micro finance is well-organized and successful instrument to decrease poverty. Although microfinance Sector in Pakistan has recognize important development and attain little cost formations. The major reason of study is to forecast that how Micro finance decreases poverty or not and method of self-employment in rural and urban of Sindh successful or not. A most important mean of this research article was to calculate that what type of Impact of microfinance on reduction of poverty and Self-employment with Supply lending and Demand following hypotheses theory. Researcher used Stratified random sampling technique 500 clients of each organization (TMB and SRSO) was selected for testing PLS with Smartpls 3. After assessment of responses with the help PLS of measurement and structural model result shows positive impact of independent variable (IV) on Dependent variables (DVs).
\end{abstract}

Key word: Micro finance(MF), Reduction of poverty(PR), self-employment(SE), Sindh rural support organization(SRSO), Telenor microfinance bank(TBM).

\section{Resumen}

Las microfinanzas son un instrumento bien organizado y exitoso para disminuir la pobreza. Aunque el Sector de microfinanzas en Pakistán ha reconocido un desarrollo importante y ha logrado formaciones de bajo costo. La razón principal de estudio es pronosticar que la forma en que las microfinanzas disminuyen la pobreza o no y el método de autoempleo en las zonas rurales y urbanas de Sindh tienen éxito o no. El medio más importante de este artículo de investigación fue calcular qué tipo de impacto de las microfinanzas sobre la reducción de la pobreza y el autoempleo con préstamos de oferta y demanda según la teoría de hipótesis. El investigador utilizó la técnica de muestreo aleatorio estratificado. Se seleccionaron 500 clientes de cada organización (TMB y SRSO) para probar PLS con Smartpls 3. Después de la evaluación de las respuestas con la ayuda, el PLS de medición y el resultado del modelo estructural muestran un impacto positivo de la variable independiente (IV) en dependientes variables (DV).

Palabra clave: Micro finanzas (MF), Reducción de la pobreza (PR), autoempleo (SE), Organización de apoyo rural de Sindh (SRSO), Banco de microfinanzas Telenor (TBM).

person, extreme poverty reduces all over the globe by 2030 (World Bank , 2018) (ADB, 2012). Microfinance: they consider offer credit to deprived was acknowledged to meaningless. financial services providers are smart by groups of needy persons because they were worried with

\footnotetext{
${ }^{5} \mathrm{PhD}$. Scholar IBA, University of Sindh.

${ }^{6}$ Professor (PhD Supervisor) IBA University of Sindh.
} 


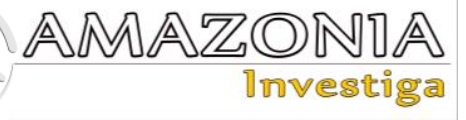

careful growth, decrease chance and have to reassurance for the reason that of uncertain situation frequently confident by funds associated crisis, disease and tragedies as well as on their concentration in trade keep administration at little scale youngsters order direction welfare offices, buy wealth and improved their anticipation for day after day relieves said by (Mohsin, Bashir, \& Tariq, 2018; Noreen, Imran, Zaheer, \& Saif, 2011).

Poverty is most important problem in our country and micro finance service providers are supporting to reduce poverty through their services. It is the primarily general common observation is that micro-finance is supportive \& for that reason everyone wants \& demands it. Like a result, there has been particularly small searching concerning to the settlement of micro finances \& until in current times small focus in tiresome to determine its particular effects.

Several research studies on impact of microfinance on poverty reduction, it works in several countries but not in all developing countries as some researcher argued that there is no impact or low impact of MF on PR but few studies use self-employment with MF other than PR as suggested by researchers (Erhardt, 2017; Kahn, Rahman, \& Wright, 2016) so, author try to explain this Self-employment variable in this research study.

The mean of this research paper is to give a clear perceptive of the micro-finance scheme in micro-finance developed states, with accent on the narrow and managerial efforts for the economic division as it affects micro-finance actions. The research paper has acknowledged the key factors of microfinance guideline and direction in our homeland, its progress, and its effect on gender equity and reduction of poverty our homeland Sindh province has been carry out.

The MFIs services are growing its persuade in the countries; for that reason, the plan of this specific research paper is to come across the probable effect of MF services lying on reduction of poverty \& self-employment with deference toward Pakistani circumstances especially in Sindh.

\section{Background of study}

Follow a line of investigation study on discovery an impact of micro/small credit on deficiency/poverty is reasonably most modern. A common of the studies on a cause of small/micro finance are accepted out afterward than 2000.
Only a few NGO's within our country conducts common study to estimation the effect of micro-finance lying on their users (Yusuf, Shirazi, \& Ghani, 2013)

Micro-finance (MF) is worldwide accepted like a valuable mechanism within reducing poverty. It prefers to fiscal services such like micro loans, micro funds; micro indemnity offered for micro- wages group. Two to three decade previously MF service contributors were a region together with a handful organizations looking to obtains superior livelihood customary of an undersized component of micro-finance marketplace although this part at this time be transformed into a well-known sector within their own right so as to offers to a variety of revenue and work partition (Khan, et al., October 2009). Enlarges of MF services contain urbanized not just here small-credit and figure of loan recipient on the other hand small- saving and small investment also (Ghanghro \& Khan, Dec 2015). Furthermore, researcher believed during a supply side desire for improvement, micro-finance experts are constantly determined for ground and consumers.

Moreover, researcher believed this sector's group in modern times apprehended a high point to speak regarding the industry's extension strategy for 2020; how to extend the dynamic consumer support of microfinance opening $3,300,000$ in 2015 to $10,000,000$ for the period of 2020. While business \& non-profit making business to addition in outreach might be different, the MF sector's progresses move toward torrents gripping and important discussion (Ghanghro \& Khan, Dec 2015).

In accumulation researchers talk about in his research several associated questions linked just before a expansion of sector, revenue also occupation and in previous are micro-finance service supplier sustaining gender fairness whereas giving credit otherwise throughout service are provided. (Ghanghro \& Khan, Dec 2015).

\section{Micro-finance Sector overview}

A micro finance division inside our country having viewed regular progress above the preceding a few years in not only small/microloan not including also small/micro savings, and small/micro insurance, is sooner to be found to contribute an important role in the complete finance region (Basharat, Arshad, \& Ali, 2014). The ordinary financed sum of the microfinance sector has enhanced initially from Rupees 
twenty-four thousand to Rupees twenty-seven thousand in 2012-13.

Telenor Microfinance Bank Ltd (TMFB) the first and largest player in supplies of portfolio capacity has a Gross credit collection of rupees. $83,000,000$ despite of a marketplace involvement toward eight point two percent in stipulations of client outreach (JCR-VIS, May 2015). This is verified from side to side TMFB's greater than standard loan amount, generally on retain of secure financing possessions which signify eighty percent of TMFB's total micro/small credit/loan portfolio. Further significant corporations including are NRSP (National Rural Support Program), National Rural Support Program \& KF (Kashf Foundation) lying on the savings element, the number of saving customers grown from part to part higher than twenty-four percent, getting elevated to 2,200,000 during 2013 whereas contrasted to $1,700,000$ during 2012. Smallest amount quantity of credit is equivalent to in excess of ten thousand and highest sum drop in 4 types first and second are salaries/ general and business/Karobar-loan quantity begins from ten thousand till One hundred fifty thousand and they are charging 18 $\%$ customers have wages limit for Four Hundred Eighty thousand and third type is housing/accommodation loan begins from Fifteen thousand till Five hundred thousand customers have wages limit for six hundred thousand.

\section{Literature review}

Several studies are supporting that there is positive and significant impact of microfinance on reduction of poverty and self-employment (Sangwan \& Nayak, 2019) (Khandker, Baqui Khalily, \& Samad, 2015) (Awan \& Ibrahim, 2015) (Yogendrarajah, 2010) these studies were conducted in Asian region like India, Bangladesh, Sirlanka and Pakistan but some researchers had argument (Kahn, Rahman, \& Wright, 2016), "Bhatt and Schreiner" in 1999 and "Sanders in 2002" (Brau \& Woller, 2004) on the same that there was no significant impact so, Author want to find out that in our homeland especially in Sindh region there in positive impact, no impact or negative impact of microfinance on reduction of poverty and self- employment. Moreover, detail of literature is given below to understand the concept of poverty reduction and self-employment.

Through situation toward this research focus investigator's independent variable is MF \& mutually dependent variables are Reduction
Poverty and Self-employment. Here Reduction of Poverty author has narrated that various variable including increase in assets, education of children and housing suggested by (Marconatto, Cruz, Moura, \& Teixeira, 2017) (Datta \& Singh, 2019) also and in self-employment some of variable like stating and expansion of business, covering-up business expenses and stating livestock and agricultural activities ( Awan \& Ibrahim, 2015) etc.

\section{Demand following and Supply lending theory.}

(Patrick, 1966) researcher suggest that supply lending theory explains that financial supply creates demand in developing country and it is appropriate way to generate self-employment/ entrepreneurship with the help of microfinance institutions said by other researcher (Chow, Vieito, \& Wong, 2018), researcher (Robinson, 1952) narrated that Demand following theory to effective and efficient utilization of economic resources that leads to financial growth and development but other researcher argues that (Murinde, 1994) development of financial services leads not followed and Researcher conclude that supply leading in only perusable when economics plan to restructured their financial sector with increased supply of fund and financial institutions as well (Chow, Vieito, \& Wong, 2018). Researcher want to include casual effect with this theory and find out the result in Sindh, Pakistan.

\section{MF and PR}

Definition of microfinance and reduction of poverty are given below "Microfinance can be defined as the provision of a broad range of financial services such as deposits, credits, payment services to the poor and low income households and their microenterprises" (HEARTH, 2018; ADB, 2000)

"Poverty is not purely about material conditions. It also refers to other forms of deprivation such as social inferiority, powerlessness and isolation. The meaning of poverty and deprivation is not merely of analytical significant; it also has a strategic dimension. An attentiveness on poverty as 'income poverty' is usually associated with a conceptualization of poverty-reduction as moving low income groups to from a stable 'below poverty line' situation to a stable 'above poverty line' situation" Said by (HEARTH, 2018)

Research literature explains that microfinance is like providing a small sum of unsecured loans or 


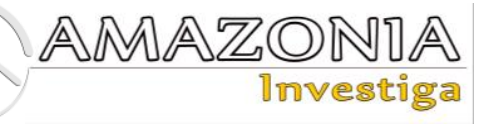

credit to the deprived or citizens in remote or city areas, supporting their personal services, incomegenerating technologies, etc., in a way that supports poor in maintaining their business. (Rudrabatla, Roy, \& Kumar, 2015) Microcredit offers a wide range of options for financial and non- fiscal products: savings, living and fitness insurance, remittances from other people to poor and poor households and its micro/small businesses (Yusuf, Shirazi, \& Ghani, 2013).

A study suggests that poverty in Pakistan has a different dimensional uniqueness, which means that the underprivileged not only have low income, but all at once have no admittance to essential services such as clean intake water, adequate hygiene, adequate schooling and access cash benefits, sufficient and adequate fitness services, service opportunities, disciplined MF marketplace for microloans. In addition, the studies show that our home country has a predictable target population of twenty-five to thirty million; the underprivileged client without PMN Associates has so far accomplished only $5 \%$ of that goal population. There is widespread technology to go at the urgent pace needed to increase the speed of development to meet the growth target of the first millennium, which is expected to be phased out by 2015 (Awan \& Ibrahim, 2015). The realization of the short period reveals that monetary expansion has declined dramatically and inflation has a poverty-based impact while responsibility for risk and direct guidance for working in poverty in the short term is not significant (Pervaiz, Ali, Chani, \& Jan, January 2011). An additional study literature proposes that small-loan twist out to be a simply decision to reduce otherwise drop a hurdle of shortage inside our mother country. Small-loans grow into a base of set so as to suitability and medicinal services, education of children, growing worth of food, housing situation for the reason that of the lively input of poor citizen to achieved a determined objectives of small-credit by MF organizations (Rudrabatla, Roy, \& Kumar, 2015).

\section{Self-Employment \& MF}

Very simple definition of self-employment suggested by researcher in his study "The simplest kind of entrepreneurship is self-employment" (Blanchflower, 2000).

The study texts propose that MF is a simple also isolated explanation for poverty reduction. Selfemployment opportunities through microcredit strategy to poverty might be eliminated and reduced. Problems of poverty possibly will be solved in order to provide power toward disadvantaged citizens through the progress of MF projects. In addition, according to his study, the researcher said that $240,000,000$ people are living underneath the poverty line, and given the capacity for microloans, the existence of this underprivileged public could be changed by providing those vulnerabilities with such job opportunities and without having their own bank accounts (Shastri, 2009).

An additional research article proposed that MF and personal small business make possible as a merger tool to provide expansion to the country's financial system. Official numeral credentials have an astonishing diversity in the amount and vividness of the personal small business price between dissimilar states and countries. Nations in which self-employ is an effective are further urban and growing economies than the modernize economies. Within these economies, self-employment figures may indicate a weakening of the capitalist category at the prior levels, or cover unimportant urban industrial workers in a simple survival phase and cover real unemployment in times of financial distress. In addition, they speculated that the range for emerging and developed economies, using the latest investigational evidence and statistical factors, will test the reasons of its range with econometric techniques. A result frequently found an unaccommodating affiliation between self-employment and enlargement: self-employment probable tempted toward retire with an expansion process. In opposition, the present evidence suggested that in a few research studies self-employed too much value-added business sales out of the country, on behalf of the alive and emerging figure of personal microventure (Awan \& Ibrahim, 2015).

\section{Methodology}

The collection of data has been done by using the most significant and usually used tool for this research study is "Questionnaire" done by other researcher (Shaheen, Hussain, \& Mujtaba, 2018), data was collected from clients of a both MFIs have been selected for filling the survey. The reason of study was carefully making clear to clients and customers microfinance organizations and banks previous receiving it filled. There are four non-probabilities as well probability supported methods of sampling. A non-parametric stratified sampling (Shaheen, Hussain, \& Mujtaba, 2018; Tariq, Aleemi, \& Iqbal, 2015) as used by other researchers so, this technique has been used for this study by researcher. Sufficient size of sample ought to be 
preferred toward signify the population. A size of sample of 1000 was preferred for this study.

Some consumers and clients are not capable to drearily fill up which have decreased the size of sample to 846 from 1000 from 9 district that are Dadu, Nawabshah, Sanghar, Naushahro Feroze, Shikarpur, Shahdadkot, Larkana, Sukkur and Ghotki out of 29 district on the bases of poverty ranking given by researcher and PBOS (Husain, Qureshi, \& Hussain, 2019; Pakistan Bureau of Statistics , 2018) Sindh 47 clients form each district of both MFIs.

Testing Software: Smartpls 3 is used for data processing by researcher.

\section{Hypothesis of Research}

A given hypotheses contain been prepared to check the association $\mathrm{b} / \mathrm{w}$ independent \& dependent's variable or factor of research paper as specified beneath:

$\mathrm{H} 1_{0}$ : MF services have no effect on reduction of poverty in Sindh.

$\mathrm{H} 1_{\mathrm{A}}$ : MF services have effect on reduction of poverty in Sindh.

$\mathrm{H} 2_{0}$ : MF services have no effect on Self-employment.

$\mathrm{H} 2 \mathrm{~A}_{\mathrm{A}}$ MF services have effect on Self-employment.

\section{Model of Research}

To accomplish the study aims, the subsequent study model has been prepared:

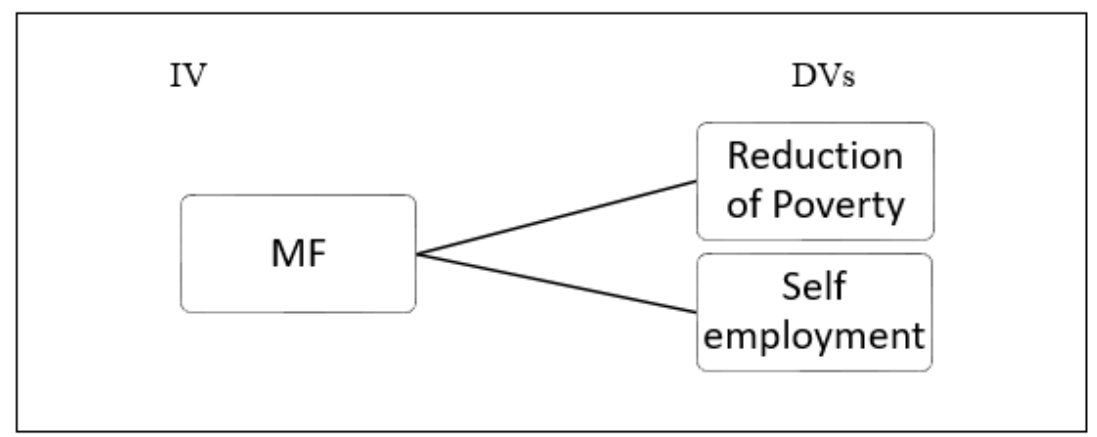

Figure 1. Model of Research.

Equations of Model explanation

$\mathrm{Y} 1=\alpha+\beta 1 \mathrm{x} 1+\mu$

$\mathrm{Y} 2=\alpha+\beta 1 \mathrm{x} 1+\mu$

$\mathrm{Y} 1=$ Reduction of poverty dependent variable

Y2= Self-employment dependent variable

$\mathrm{a}=$ population intercepts

$\beta=$ coefficients regression

$\mathrm{X}_{1}=$ microfinance as independent variable $\mu=$ Error

\section{Results and discussion}

Research start with analysis of result of measurement model in this first and foremost is reliability of data in Table. 1, it means consistency of data. Recommended range of constructive reliability is from 0.70 to 0.99 and all variables Microfinance, Reduction of poverty and Self-employment are in acceptable range according to citation. Moreover, for convergent validity researcher AVE and acceptable value is above 0.50 and again all variable values are acceptable (Hair, Risher, Sarstedt, \& Ringle, 2019) therefore the data is consistency and accuracy good for further testing.

Table 1.

Construct Reliability and Validity.

\begin{tabular}{lllll}
\hline & Cronbach's Alpha & rho_A & $\begin{array}{l}\text { Composite } \\
\text { Reliability }\end{array}$ & $\begin{array}{l}\text { Average Variance Extracted } \\
\text { (AVE) }\end{array}$ \\
\hline MF & 0.849 & 0.853 & 0.892 & 0.624 \\
PR & 0.857 & 0.865 & 0.891 & 0.541 \\
SE & 0.875 & 0.889 & 0.901 & 0.566 \\
\hline
\end{tabular}




\section{AMAZONIA \\ Investiga}

In validity testing another recommended and important test is Discriminant validity for research. It includes Fornell \& lacker criterion, cross loading and hetero trait mono trait. In Discriminant validity explains latent variables have several indicator representatives for constructs. It explains and analysis the magnitude to which indicators and variables are different

Table 2.

Discriminant Validity.

\begin{tabular}{llll}
\hline Fornell-Larcker Criterion & & & \\
\hline & MF & PR & SE \\
MF & 0.790 & & \\
PR & 0.559 & 0.735 & \\
SE & 0.711 & 0.644 & 0.752 \\
\hline
\end{tabular}

Another discriminant validity criteria is cross loading, which explained that the element loadings of indicators of allocated constructs essentially have values greater than loadings of another constructs (Fornell \& Larcker, 1981; among each other. 1st test of validity Fornelllacker criterion compare with square root of AVE with the correlation of latent variable ( Hair, Hult, Ringle, \& Sarstedt, 2014). Moreover, all diagonal values are greater than non-diagonal (Fornell \& Larcker, 1981) same as in table 2(a) so data demonstrate discriminant validity $1 \mathrm{st}$ criteri

Table 3.

Discriminant Validity.

\begin{tabular}{llll}
\hline Cross Loadings & & & \\
\hline & MF & PR & SE \\
M1 & $\mathbf{0 . 8 1 0}$ & 0.461 & 0.586 \\
M2 & $\mathbf{0 . 8 2 8}$ & 0.431 & 0.608 \\
M3 & $\mathbf{0 . 7 5 4}$ & 0.385 & 0.457 \\
M4 & $\mathbf{0 . 7 4 5}$ & 0.487 & 0.624 \\
M5 & $\mathbf{0 . 8 0 8}$ & 0.427 & 0.498 \\
P1 & 0.438 & $\mathbf{0 . 6 1 5}$ & 0.377 \\
P2 & 0.441 & $\mathbf{0 . 7 6 1}$ & 0.414 \\
P3 & 0.470 & $\mathbf{0 . 8 2 0}$ & 0.502 \\
P4 & 0.267 & $\mathbf{0 . 6 6 2}$ & 0.381 \\
P5 & 0.455 & $\mathbf{0 . 8 0 6}$ & 0.562 \\
P6 & 0.401 & $\mathbf{0 . 7 2 9}$ & 0.540 \\
P7 & 0.335 & $\mathbf{0 . 7 3 1}$ & 0.526 \\
SE1 & 0.525 & 0.486 & $\mathbf{0 . 8 1 7}$ \\
SE2 & 0.674 & 0.559 & $\mathbf{0 . 8 1 3}$ \\
SE3 & 0.433 & 0.441 & $\mathbf{0 . 7 3 9}$ \\
SE4 & 0.638 & 0.501 & $\mathbf{0 . 7 0 0}$ \\
SE5 & 0.577 & 0.506 & $\mathbf{0 . 8 0 7}$ \\
SE6 & 0.395 & 0.460 & $\mathbf{0 . 7 0 0}$ \\
SE7. & 0.344 & 0.390 & $\mathbf{0 . 6 7 4}$ \\
\hline
\end{tabular}

According to different studies in discriminant validity $3 \mathrm{rd}$ criteria is HTMT values must be less than 0.85 are acceptable (Sidek, Sami, \& Hamid, 2017; Hair, Risher, Sarstedt, \& Ringle, 2019) in
Hair, Hult, Ringle, \& Sarstedt, 2014) and in table 3 all values of cross- loadings for constructs is greater than all other constructs so it meets the criteria of discriminant validity according to citations. table 4 given below values are less than 0.85 and acceptable so researcher's data have no issue of discriminant validity. 
Table 4.

Discriminant Validity.

\begin{tabular}{llll}
\hline Heterotrait-Monotrait Ratio (HTMT) & & & \\
\hline & MF & PR & SE \\
MF & & & \\
PR & 0.633 & & \\
SE & 0.775 & 0.733 & \\
\hline
\end{tabular}

According to $\mathrm{R} 2$ researcher the range of $\mathrm{R} 2$ is from 0 to 1 , with lower value indicates had no predictive power or no explanatory power so rule of thumb $0,0.25,0.50$, and 0.75 values has no, weak, moderate and sustainable predictive power or explanatory power (Hair, Risher, Sarstedt, \& Ringle, 2019). According to table 5 value R2 0.313 is showing Poverty Reduction and it seven indicators that are purchase of durable good, improve living standard, improve quality of education, improve medical facilities, improve status of accommodation and improve food \& water quality had explained $31.3 \%$ of variance by microfinance and its five indicators that are rate of interest, MF services, micro-loan as tool of prosperities, micro-saving and microloan amount received. Another value R2 0.505 is showing MF and its indicators are explaining $50.5 \%$ variance with self-employment and its indicators.

Table 5.

$R$ Square.

\begin{tabular}{lll}
\hline & R Square & R Square Adjusted \\
\hline PR & 0.313 & 0.312 \\
SE & 0.505 & 0.505 \\
\hline
\end{tabular}

Table 6.

Blindfolding.

\begin{tabular}{|c|c|c|c|}
\hline \multicolumn{4}{|c|}{ Construct Cross Validated Redundancy Total } \\
\hline & SSO & SSE & $\mathrm{Q}^{2}(=1-\mathrm{SSE} / \mathrm{SSO})$ \\
\hline MF & 4230.000 & 4230.000 & \\
\hline PR & 5922.000 & 4971.320 & 0.161 \\
\hline SE & 5922.000 & 4371.925 & 0.262 \\
\hline
\end{tabular}

Above mention table 6 Blindfolding Construct Cross Validated Redundancy is for predictive relevance purpose in which criteria is $\mathrm{Q}^{2}$ value > 0 is meaningful if $\mathrm{Q}^{2}$ value $>0,0.25$ and 0.50 minor, moderate and strong predictive relevance (Hair, Risher, Sarstedt, \& Ringle, 2019). Above table 5 mention $\mathrm{Q}^{2}$ values of $\mathrm{PR}$ and $\mathrm{SE}$ are greater than 0 so, PLS model has predictive relevance.

Researcher analysis of result of Structural model with bootstrapping path coefficients and
Blindfolding Construct Cross Validated Redundancy to verify hypothesis. Figure 1 shows factor loading of each indicator recommended loading is above 0.7 or above 0.65 ( Hair, Hult, Ringle, \& Sarstedt, 2014) but if it lower than 0.6 and not effecting reliability and validity of data so there no harm to remove that indicators from model (Hair, Risher, Sarstedt, \& Ringle, 2019) here we have P1 loading is 0.615 but don't effect on overall results so researcher dose not remove it. 


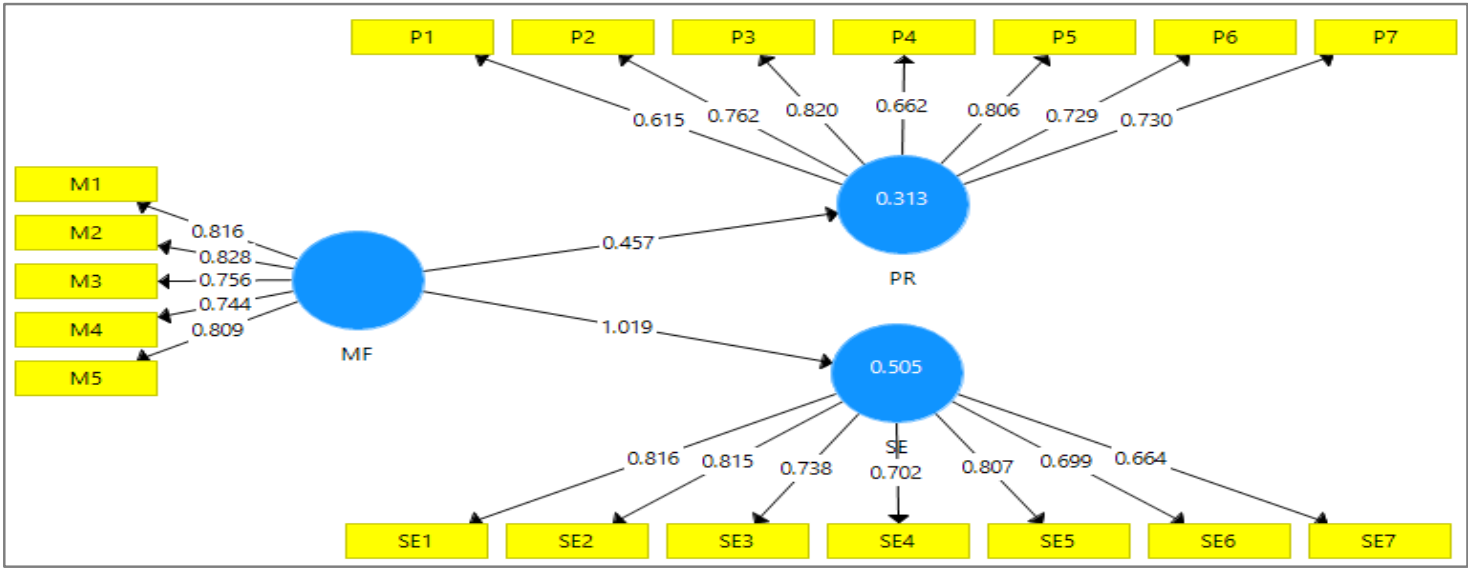

Figure 2. Bootstrapping Path Coefficients.

Table 7.

Bootstrapping Path Coefficients.

\begin{tabular}{llllll}
\hline \multicolumn{4}{l}{ Mean, STDEV, T-Values, P-Values } & & \\
\hline & $\begin{array}{l}\text { Original } \\
\text { Sample }(\mathbf{O})\end{array}$ & $\begin{array}{l}\text { Sample Mean } \\
(\mathbf{M})\end{array}$ & $\begin{array}{l}\text { Standard Deviation } \\
(\text { STDEV) }\end{array}$ & $\begin{array}{l}\text { T Statistics } \\
(\mid \mathbf{O} / \text { STDEV })\end{array}$ & P Values \\
MF $->$ & 0.559 & 0.558 & 0.050 & 11.272 & $\mathbf{0 . 0 0 0}$ \\
$\begin{array}{l}\text { PR } \\
\text { MF }->\end{array}$ & 0.711 & 0.710 & 0.036 & 19.833 & $\mathbf{0 . 0 0 0}$ \\
SE & & & & \\
\hline
\end{tabular}

Above table 7 bootstrapping path coefficients mention the values of original sample, sample Mean, Standard Deviation, $\mathrm{T}$ statistics and $\mathrm{P}$ value. Researcher narrated that $P$ values less than 0.05 and $T$ values greater than 2 are acceptable as statistically significant (Hair, Risher, Sarstedt, \& Ringle, 2019). Hence with relationship of microfinance and poverty $\mathrm{T}$ value is $11.272>2$ and $\mathrm{P}$ value $<0.05$ both values are showing there is impact of MF on PR so, reject null hypotheses and for self-employment $\mathrm{T}$ value is $19.833>2$ and $\mathrm{P}$ value $<0.05$ both values are showing there is impact of MF on SE therefore researcher reject null hypotheses, these results are showing similarity as other studies (Khanam, Mohiuddin, Hoque, \& Webe, 2018; Awan \& Ibrahim, 2015) shown in other areas of Pakistan and world as well.

\section{Conclusion}

Researcher conclude that after analyzing data with PLS (measurement model and Structural Model) there is no reliability and no validity issue in responses after that researcher R2 and Q2 values proves that research both hypotheses are accepted in the scenario of Sindh, both organizations clients are agreeing with the high rate of interest charges on their microloans, satisfied with services provided by MFIs, they are satisfied with microloan amount requested from organization and microloan amount received around 90 to $95 \%$, they increase their micro saving amount after getting microloan.

Moreover, they improve their living standard, improve quality of food, education (primary and higher level), medical facilities, improve accommodation, increase their durable assets, with this citizen/ clients of MFIs increase their level of standard from lower level to middle level in their range.

Furthermore, clients commence new startup, agricultural production increase by increasing land area on rent or acquiring a piece, increase livestock for dairy farming and trading livestock after getting agricultural microloan, expand their small business, rise their business income level and easily covering their business expenses with microfinance business or emprises loan in rural and urban areas of nine Districts of Sindh.

Researcher conclude and suggest that TMB and SRSO will provide their services in those rural and urban area of Sindh where they are not serving up till now because potential clients of microfinance are demanding for supply of services, and in some areas supply lending hypothesis impact increase demand. 


\section{Bibliography}

ADB. (2000). Finance for the Poor.Microfinance Development Strategy, Manila. Asian Development Bank (ADB).

ADB. (2012). Microfinance development strategy 2000 Sector Performance and Client Welfare.

Awan, A. G., \& Ibrahim, M. A. (2015). Role of Micro-Financing in Creation of SelfEmployment in Pakistan: A Case Study of District Bahawalpur. Journal of economics and sustainable development.

Awan, P. A., \& Ibrahim, M. A. (2015). Role of Micro-Financing in Creation of SelfEmployment in Pakistan: A Case Study of District Bahawalpur. Journal of Economics and Sustainable Development Vol.6, No.7, 38-45.

Basharat, A., Arshad, A., \& Ali, K. (2014). Pakistan Microfinance Review 2014. Pakistan Microfinance Network.

Blanchflower, D. G. (2000). Self-employment in OECD countries. Labour Economics, 7, 471-505. doi:https://doi.org/10.1016/S0927-

5371(00)00011-7

Brau, J. C., \& Woller, G. M. (2004). Microfinance: A Comprehensive Review of the Existing Literature. The Journal of Entrepreneurial Finance, 9(1). Retrieved from http://digitalcommons.pepperdine.edu/jef/vol9/i ss $1 / 2$

Chow, S., Vieito, J., \& Wong, W. K. (2018, June 26). Do both demand-following and supply-leading theories hold true in developing countries? Munich Personal RePEc Archive, 1-41. doi:https://mpra.ub.unimuenchen.de/87641/

Datta, S. K., \& Singh, K. (2019, July 15). Variation and Determinants of Financial Inclusion and association with Human Development: A Cross Country Analysis. IMB Management Review. doi:https://doi.org/10.1016/j.iimb.2019.07.013 Erhardt, E. (2017, April 27). Microfinance beyond self-employment: evidence for firms in Bulgaria. Labour Economics, 47, 75-95. doi:http://dx.doi.org/10.1016/j.labeco.2017.04.0 09

Fornell , C., \& Larcker, D. F. (1981). Evaluating Structural Equation Models with Unobservable Variables and Measurement Error. Journal of Marketing Research, 18(1), 39-50.

Ghanghro, A. A., \& Khan, N. (Dec 2015). Estimating Potential Market size for Microcredit in Pakistan. Pakistna Microfinance Network.

Hair, J. F., Hult, G. M., Ringle, C. M., \& Sarstedt, M. (2014). A Primer on Partial Least Squares Structural Equation Modeling (PLS-SEM)
(Vol. Second Edition). Los Angeles: SAGE Publications, Inc.

Hair, J. F., Risher, J. J., Sarstedt, M., \& Ringle, C. M. (2019). When to use and how to report the results of PLS-SEM. European Business Review, 31(1), 2-24. doi:https://doi.org/10.1108/EBR-112018-0203

Hearth, H. (2018). MICROFINANCE T h e o r y and $\mathrm{P}$ r a c t i c e, (Vol. First Edition). Kularatne Mawatha, Colombo, Sri Lanka: S. Godage \& Brothers (Pvt) Ltd.

Husain, I., Qureshi, A. A., \& Hussain, N. (2019). The Economy of Modern Sindh Opportunities Lost and Lessons for the Future. Karachi: OXFORD University press.

JCR-VIS. (May 2015). Microfinance Sector. JCR-VIS Credit Rating Company Limited.

Kahn, A., Rahman, T., \& Wright, R. (2016, July). The Impact of Micro-Credit on Employment: Evidence from Bangladesh and Pakistan. IZA Discussion Paper.

Khan, ,. M., Zhuang, J., Gunatilake, H., Niimi, Y., Jiang, Y., Hasan, R., \& Khor, N. (October 2009). Financial Sector Development, Economic Growth, Financial Sector Development, Economic Growth,. ADB Economics Working Paper Series No. 173.

Khanam, D., Mohiuddin, M., Hoque, A., \& Webe, O. (2018). Financing micro-entrepreneurs for poverty alleviation: a performance analysis of microfinance services offered by BRAC, ASA, and Proshika from Bangladesh. Journal of Global Entrepreneurship Research. doi:https://doi.org/10.1186/s40497-018-0114-6 Khandker, S. R., Baqui Khalily, M. A., \& Samad, H. A. (2015). Mitigating seasonal hunger with microfinance in Bangladesh: how does a flexible programme compare with the regular ones? Journal of Development Effectiveness, 7(1), 23-42.

doi:https://doi.org/10.1080/19439342.2014.988 166

Marconatto, D. A., Cruz, L. B., Moura, G. L., \& Teixeira, E. G. (2017). Why the microfinance institutions exist: lending groups as a mechanism to enhance informational symmetry and enforcement activities. O\&S - Salvador, v. 24, (n. 83), 633-654.

Mohsin, S., Bashir, M. F., \& Tariq, Y. B. (2018, Sep 28). Outreach and Performance Analysis of Microfinance Bank of Pakistan. Business \& Economic Review, Vol. 10, (No.3), pp. 21-40.

Murinde, V. E. (1994). Financial development and economic growth in Singapore:demandfollowing or supply-leading?,. Applied Financial Economics, 4(6), 391-404.

Noreen, U., Imran, R., Zaheer, A., \& Saif, M. I. (2011). Impact of Microfinance on Poverty: A 


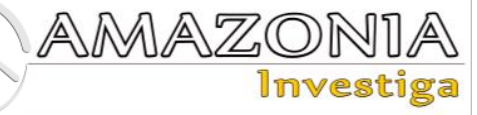

Case of Pakistan. World Applied Sciences Journal 12, 877-883.

Pakistan Bureau of Statistics. (2018, January 03). Block Wise Provisional Summary Results of 6th Population \& Housing Census-2017. Retrieved July 05, 2020, from Pakistan Bureau of Statistics (PBS): http://www.pbs.gov.pk/content/blockwise-provisional-summary-results-6thpopulation-housing-census-2017-january-032018

Patrick, H. (1966). Financial development and economic growth in underdeveloped countries. Economic development and Cultural change, 14(2), 174-189.

Pervaiz, Z., Ali, D. A., Chani, M. I., \& Jan, s. a. (January 2011). Poverty, Inflation and Economic Growth: Empirical Evidence from Pakistan. world Applied sciences journal, 1058-1063.

Robinson, J. (1952). The generalization of the general theory In: the rate of interest and other essays. London: MacMillan.

Rudrabatla, R., Roy, S., \& Kumar, K. (2015). Role of Microfinance for Improving Quality of Life by Providing Financial Services to Lowincome Group: A Critical Review. International Journal of Applied Engineering Research, ISSN 0973-4562 Vol. 10 No.55.

Sangwan, S., \& Nayak, N. C. (2019, MAy 07). Do outreach approaches differ between Self Help Group Bank Linkage and Microfinance Institution based microfinance? Evidences from Indian states. Journal of Social and Economic Development.

doi:https://doi.org/10.1007/s40847-019-00078$\mathrm{w}$

Shaheen, I., Hussain, I. \& Mujtaba, G. (2018). Role of Microfinance in Economic Empowerment of Women in Lahore, Pakistan: A Study of Akhuwat Supported Women Clients. International Journal of Economics and Financial Issues, 8(2), 337-343.

Shastri. (2009). Microfinance and Poverty Reduction in India A Comparative Study with Asian Countyries. African Journal of Business Management ., 136-140.

Sidek, M. H., Sami, W. \& Hamid, M. R. (2017). Discriminant Validity Assessment: Use of Fornell \& Larcker Criterion Versus HTMT Criterion. Journal of Physics: Conference Series, 890, 1-5. doi:https://doi.org/10.1088/17426596/890/1/012163.

Tariq, M., Aleemi, A. R., \& Iqbal, D. A. (2015, Fall). Investigating the role of micro finance on economic and social development of people: a case study areas of sind, Pakistan. IBT Journal of Business Studies (Formerly Journal of Management \& Social Sciences), Vol. 11, (No. 2,), 182-199.

World Bank . (2018). Report of the World Bank on poverty statistics. United Nations Economic and Social Council.

Yogendrarajah, R. (2010). The impact of micro credit on self employment of women - A survey on Jaffna District, SRI Lanka. 1-15. Retrieved from http://ssrn.com/abstract $=2505428$

Yusuf, M.-B. O., Shirazi, N. S., \& Ghani, G. M. (2013). The Impact of Pakistan Poverty Alleviation Fund on Poverty in Pakistan: An Empirical Analysis. Middle-East Journal of Scientific Research 13 (10), 1335-1344. 